\title{
Attitudes and Concerns of Pre-Service Teachers' about Inclusive Education Enshrined in the New Four-Year Basic Education Curriculum in Ghana
}

\author{
C. A. Issaka, M. Nyaaba, F. A. Iddrisu
}

ABSTRACT

Inclusive education, that is, the inclusion of learners with special educational needs and disabilities into regular schools is now one of the most significant core pillars in the New Bachelor of Education (Basic Education) Curriculum for teacher education in Ghana. In order to address this issue, pre-service teachers in their first year per the curriculum are introduced to inclusive education as a subject. The study aimed at finding out the attitude and concerns of pre-service teachers towards inclusive education in Ghana. The study employed mixed method approach with the sequential explanatory strategy. The sample population composed of 562 students from six (6) colleges of education in Ghana under one mentor university. The quantitative research approach consisted of 10-item questionnaire which was adapted from the Teachers' Attitudes towards Inclusive Education (TAIS) scale. Data was collected using both the questionnaire and interview guide. The analysis of quantitative data involved the use of multiple statistical procedures; frequency counts, simple percentages, and standard deviation, while the thematic analysis was used to analyze the qualitative data. The study revealed that pre-service teachers has positive attitude towards the implementation of inclusive education in Ghana. About eighty percent $(\mathbf{8 0 . 1 \%})$ stated that children with special educational needs can be effectively supported to learn in regular classrooms in Ghana (1.30, $\mathrm{SD}=.64)$. However, the current regular schools in Ghana cannot accommodate children with special needs education $(1.25, \mathrm{SD}=.62)$ due to inadequate space. It is therefore recommended that the government of Ghana and the Ghana Education Service should work together to ensure that there is the availability of adequate facilities in all schools for teachers to effectively implement inclusive education in the new Bachelor of Education (Basic Education) Curriculum

Keywords: Attitude, Concerns, Inclusive Education, New B. Ed Basic Education Curriculum, Pre-Service Teachers

Published Online: February 16, 2022

ISSN: $2736-4534$

DOI :10.24018/ejedu.2022.3.1.239

C. A. Issaka*

Faculty of Education, Department of Educational Foundations Studies. University for Development Studies, Ghana.

(e-mail: alirashuds@ gmail.com)

M. Nyaaba

Department of Education, Gambaga

College of Education, Ghana.

(e-mail: mnyaaba ${ }^{\circledR}$ gacoe.edu.gh)

F. A. Iddrisu

Tamale Technical University, Ghana.

(e-mail: abu.fati@gmail.com)

*Corresponding Author

\section{INTRODUCTION}

In Ghana, all citizens have the right to an equitable and high-quality education, yet learners' learning requirements vary, affecting access, quality, and the right to education in general. This necessitated that all actors in the educational sector accommodate the varying requirements of the various categories of learners in Ghana. The concept of inclusive education was created, which aims to maximize the potential of all students by bringing them together in one classroom and community, regardless of their strengths or deficiencies in any area (Singh, 2014).

The concept of inclusive education became internationally famous through the Salamanca Statement (UNESCO, 1994). As a result, Inclusive Education (IE) is a novel way to educate children with disabilities and learning challenges alongside their peers under the same roof. Singh
(2014). Inclusive education was first defined by UNESCO (1994, p. viii) as "allowing students with exceptional educational requirements to attend mainstream schools while also providing them with child-centered pedagogy capable of addressing their educational needs." This has been reinforced by Sustainable Development Goal 4, which calls on the globe to guarantee that all people have access to inclusive and equitable quality education in order to promote lifelong learning opportunities.

The curriculum for the Ghana Teacher Education Division has received remarkable reforms from the precolonial through colonial to the post-colonial era. Recently, the Cabinet of Ghana approved the Policy for the Initial Teacher Education (ITE) Reforms for Basic Education and Training. The reforms introduced a New Bachelor of Education (Basic Education) Curriculum which outlines inclusive education as one of its key pillars. As part of the 
policy the curriculum ensures that all pre-service teacher training courses at the Colleges of Education must include inclusive education training to prepare teachers to deal with diversity in the classroom and provide them with relevant teaching and learning competencies and methods to fulfill the needs of all students (MOE, 2018).

This clearly indicates that unlike the previous special schools for special need children, all special needs children would be accommodated in the regular school settings except in cases where the Ministries responsible for Education, Health and Social Welfare have assessed the child and concluded that the regular school may not be the best placement for the child's education.

Consequently, inclusive education has become one of the most significant core subjects in the New Bachelor of Education Curriculum, Basic Education, for all teacher education in Ghana. Pre-service teachers in the first year of the curriculum are introduced to inclusive education and this is aimed at equipping them to understand concepts and acquire the competencies to ensure the effective realization of the inclusive education policy in Ghana (MOE, 2018).

Pre-service teachers' attitude and concerns have a tremendous influence on the success of implementing inclusive educational approaches (Forlin et al., 2008). Likewise, Gibb et al. (2007) also posited that the attitude and concerns of student teachers have a major impact on the success of the implementation of inclusive education.

Therefore, this study sought to answer two broad questions: What is the attitude of pre-service teachers towards Inclusive Education on the New Bachelor of Education Curriculum for Basic Education and Training among the UDS affiliated colleges of Education? What concerns do pre-service teachers have about the Inclusive Education content in the New Bachelor of Education Curriculum for Basic Education and Training among the affiliated colleges under UDS? The purpose of this study was thus to explore the attitudes and concerns of pre-service teachers towards inclusive education.

\section{LITERATURE REVIEW}

\section{A. Pre-Service Teachers' Attitudes towards Inclusive Education}

Attitude has a significant impact on directing a person's behavior. Affective and positive behaviors toward an object are influenced by one's attitude toward it. There is no question that pre-service and in-service teachers' attitudes influence the success of inclusive education implementation (Dias \& Cadime, 2016). According to Kraska and Boyle (2014), pre-service teacher attitudes toward inclusion are critical because they can predict future attitudes during their teaching careers.

Kraska and Boyle's (2014) found preservice teachers' attitudes toward inclusive education to be positive. Particularly when they are exposed to inclusive education modules, Preservice teachers develop the notion that they have received the training and ability to educate children with a variety of needs. (Subban \& Sharma, 2005; Sharma et al., 2008). Teachers who had received special education training, according to Varcoe and Boyle (2014), had even more favourable opinions regarding inclusive education. Preservice teachers develop the notion that they have received the training and ability to educate children with a variety of needs (Sharma et al., 2008; Subban \& Sharma, 2005). Teachers who had received special education training, according to Varcoe and Boyle (2014), had even more favourable opinions regarding inclusive education. Goddard and Evans (2018) found that pre-service teachers' attitudes towards inclusion were generally positive.

Teachers that have a strong unfavorable attitude toward special needs children can be uncomfortable in the classroom, according to Costello and Boyle (2013), which can lead to negative expectations and interactions with special needs children (Markova et al., 2016). In order to embrace special needs children in the framework of inclusive education, pre-service teachers' attitudes are critical (Todorovic et al., 2011).

The attitudes held by pre-service teachers affect their willingness and ability to implement an inclusive approach to education (Costello \& Boyle, 2013). Several factors can influence pre-service teachers' attitudes toward special needs children. Kim and Taylor (2016) discovered that preservice teachers who had teaching experience with special needs children in an inclusive education context had a more positive attitude toward inclusive education. Sokal and Sharma (2017) have demonstrated that pre-service teachers' attitudes are influenced by their teaching experience with special needs students. Pre-service teachers' views toward special needs children are influenced by study programs, according to Markova et al. (2016).

According to Altintaş and Engül (2014), instructors' attitudes not only determine the teacher-mainstreamed student interaction, but they also play a significant role in generating expectations for mainstreamed students' performance and in the attitudes of other students toward them. According to previous research, educational innovations such as inclusive education are unlikely to succeed if educators hold negative sentiments (Avramidis et al., 2000; Treder et al., 2000). When students with disabilities and those with a variety of learning requirements are placed in their classrooms, teachers' negative attitudes regarding their inclusion are likely to influence their behavior (Sharma et al., 2007). According to studies, teachers' attitudes toward inclusive education are influenced by a lack of special education training (Leatherman \& Niemeyer, 2005), a lack of contact with someone with a disability (Avramidis \& Norwich, 2002), and a lack of confidence in teaching students with disabilities (Zanandrea \& Rizzo, 1998).

\section{B. Concerns of Pre-Service Teachers about Inclusive Education}

Inasmuch as in-service teacher professional development is beneficial, greater focus is being placed on general educators' pre-service training (Hemmings \& Woodcock, 2011). One of the concerns of teachers in inclusive classroom is inadequate training in inclusive education (Symeonidou \& Phtiaka, 2009). According to Ahmadi and Bukamal (2019), during their school practicum, candidate teachers needed additional opportunities to connect with and teach students with impairments, according to the findings. 
to prepare them adequately to teach students with diverse learning needs in inclusive classrooms. They found the sentiments of the preservice teachers to be positive and compassionate towards children with special educational needs though they also expressed some apprehensions in regard to including children who exhibit aggressive behavior in regular classes.

Sharma, Loreman and Forlin (2007) indicated that a large degree of variance in teachers' attitudes still remains unexplained and it seems reasonable to look for variables that are closely associated with attitudes and concerns about inclusion appear to be one such variable. Teachers may be concerned about issues such as lack of support services; lack of skills and knowledge to implement inclusion large class sizes; lack of time and working with students who display disruptive behaviors (Smith \& Smith, 2000). Also, educators express concerns about their inadequacy to respond to the special needs of special needs students who are included in their classes (Snyder, 1999; Wiley, 1993).

Educators who have undergone training in special education are concerned that their training has not prepared them adequately to work in inclusive settings (Smith \& Smith, 2000). Although educators are willing to undergo relevant, ongoing professional development directed at inclusive education practices that such training is often not available, thereby, adding to their concerns (Pearman, Huang, \& Mellblom, 1997; Snyder, 1999). Wiley (1993) examined in-service and pre-service teachers' attitudes and concerns about the integration of children with special needs into the regular school and inadequate training in special education, and lack of the confidence as the major concerns expressed by both preservice and in-service teachers.

\section{MethodolOGY}

A descriptive survey research design using a mixed technique approach was used in this study. The explanatory sequential strategy was used in the mixed method approach. In the explanatory sequential strategy, the first phase of research is defined by the collection and analysis of quantitative data, followed by the acquisition and analysis of qualitative data that builds on the results of the initial quantitative results (Creswell, 2008). The explanatory sequential strategy ensures follow-up of a qualitative data collection after quantitative analysis to reveal the entire picture of the research.

In the phase of quantitative data collection, 10-item questionnaire adapted from the Teachers' Attitudes towards Inclusive Education (TAIS) scale was used with the help of Google Forms to reach out to college students in six (6) colleges of education in Ghana to collect data on student teachers' perception about inclusive education (Saloviita, 2015). The items on the questionnaire were rated on a-5point Likert scale of $1-5$ with a mean of 3 . Using the Likert scale for the ten items on the questionnaire, a descriptive statistics was used to analyze the data collected. Each item consisted of a statement followed by a five weighted options; Strongly Agree $(\mathrm{SA})=1$, Agree $(\mathrm{A})=2$, None $(\mathrm{N})$ $=3$, Disagree $(\mathrm{D})=4$ and Strongly Disagree $(\mathrm{SD})=5$. For the purposes of analysis and easy conclusion, Strongly Agree and Agree were merged as 'Agree' whereas |Disagree and Strongly Disagree were also merged as 'Disagree'. The sample was made up of 562 colleges of education students from the six (6) colleges of education.

Mentor University superintends these six (6) colleges of education which the researchers are staff members, hence, making it convenient for data collection. The responses received from a sample of five hundred and sixty-two (562) pre-service teachers were analyzed. In the phase of qualitative data collection, an interview guide was used to seek further concerns about inclusive education from 20 students among the six (6) colleges of education. The guide was designed from predetermined themes generated from the results of the quantitative data. Due to data saturation, at least $2 \%$ of the participants in the quantitative data collection from each of the colleges constituted the sample for the interview data collection.

\section{DATA ANALYSIS}

The participants' responses to the questionnaire were organized into frequency counts, and converted into percentages. The results were used to describe attitude of the pre-service teachers towards inclusive education in Ghana. Respondents' with mean scores less than the average mean of 3.0 were considered to have positive attitude while respondents with mean scores greater than 3.0 were considered to have negative attitude. Negative worded items were recoded. The frequency and percentages were also used to analyze and describe the respondents' attitude. The results are presented in Table I. The interview was analysed thematically based on the predetermined themes such as, how special education needs learners should be treated, the appropriateness of inclusive education in Ghana, etc.

\section{RESUlts}

A total of 562 colleges of education students from the six (6) colleges of education made up the sample of the study. The biographic data of the participants was gathered via the study's questionnaire.

\section{A. Background Information of the Respondents of the Study}

The study involved first year students of the six affiliate colleges of education of the University for Development Studies. The age range of participants was between 16 to 30 years. Three hundred and nine males and 253 females participated in the study.

\section{B. Pre-Service Teachers' Attitude towards Inclusive Education in Ghana}

The researchers sought to ascertain pre-service teachers' attitude towards inclusive education. Using the Likert scale for the ten items on the questionnaire, a descriptive statistics was used to analyze the data collected. 
TABLE I: Descriptive Statistics of Pre-SERvice Teachers' PercePtion ABout InClusive EduCATION GHana

\begin{tabular}{|c|c|c|c|c|c|}
\hline Items & A & $\mathrm{N}$ & $\mathrm{D}$ & $\mathrm{M}$ & $\mathrm{SD}$ \\
\hline $\begin{array}{l}\text { To avoid violating a child's legal right to education, he or she should be moved to a } \\
\text { special need slassroom. }\end{array}$ & $282(50.2)$ & $56(10.0)$ & $224(39.8)$ & 1.90 & 0.94 \\
\hline $\begin{array}{c}\text { The learning of children with special educational needs can effectively be supported in } \\
\text { regular classroom in Ghana. }\end{array}$ & $450(80.1)$ & 56 (10.) & $56(10.0)$ & 1.30 & 0.64 \\
\hline $\begin{array}{l}\text { If each child with special education needs is placed in a special classroom that best suits } \\
\text { him or her, the best results will not be achieved. }\end{array}$ & $365(64.9)$ & $28(5.0)$ & $169(30.1)$ & 2.35 & 0.91 \\
\hline $\begin{array}{l}\text { Special education schools with well-trained special teachers are the ideal places for } \\
\text { children with special educational needs to learn. }\end{array}$ & $309(55.0)$ & $56(10.0)$ & $197(35.1)$ & 1.80 & 0.93 \\
\hline $\begin{array}{l}\text { In Ghana, it is a child's right to attend a special educational classroom if he or she has } \\
\text { special educational requirements. }\end{array}$ & $197(35.1)$ & $56(10.0)$ & $309(55.0)$ & 2.20 & 0.93 \\
\hline $\begin{array}{l}\text { Children with special education needs can be admitted into regular classroom in Ghana } \\
\text { with adequate support }\end{array}$ & $281(50.0)$ & $28(5.0)$ & $253(45.0)$ & 1.95 & 0.97 \\
\hline $\begin{array}{c}\text { Teachers in Ghana's regular classrooms will have more work to do as a result of } \\
\text { integrating children with special needs in schools. }\end{array}$ & $337(60.0)$ & $85(15.1)$ & $140(24.9)$ & 1.65 & 0.85 \\
\hline $\begin{array}{c}\text { The education of children with special needs should be arranged as far possible in } \\
\text { regular classrooms in Ghana }\end{array}$ & $421(74.9)$ & $56(10.0)$ & $85(15.1)$ & 1.40 & 0.74 \\
\hline $\begin{array}{l}\text { The current regular schools in Ghana can't accommodate children with special need } \\
\text { education }\end{array}$ & $478(85.1)$ & $28(5.0)$ & $56(10.0)$ & 1.25 & 0.62 \\
\hline $\begin{array}{l}\text { With my knowledge in inclusive education I think it is possible to be implemented in } \\
\text { Ghana }\end{array}$ & $478(85.1)$ & $28(5.0)$ & $56(10.0)$ & 1.25 & 0.62 \\
\hline
\end{tabular}

The means of the elements in the table ranged from 1.25 to 2.35 , with SDs ranging from 0.62 to 0.97 . The items with the lowest mean $(1.25, \mathrm{SD}=0.62)$ were on 'the current regular schools in Ghana can't accommodate children with special need education' and 'with my knowledge in inclusive education I think it is possible to be implemented in Ghana', and the highest mean $(2.35, \mathrm{SD}=0.91)$ was on the statement 'the best results would not be achieved if each child with special education needs is placed in a special classroom that best suits him/her'. The percentages were used for further discussion of the findings.

Based on pre-service teachers' knowledge in inclusive education as they acquired through their first semester course, majority $(85.1 \%)$ of them agreed to the statement that it is possible for inclusive education to be implemented in Ghana. However, equal number of pre-service students $(85.1 \%)$ believed that the current regular schools in Ghana can't accommodate children with special need education. Therefore, the education of children with special needs should be arranged as far as possible in regular classrooms in Ghana. This finding fosters Nketsia and Saloviita (2013) study that indicated that only one-third of pre-service teachers in Ghana felt highly, or somewhat, believed that inclusive education is possible in Ghana.

Half of the pre-service teachers $(50 \%)$ were of the view that children with special need education should be admitted in the regular schools in Ghana though fifty-five percent $(55 \%)$ of them indicated that children with special educational needs may learn best in a special education schools where they have well trained special teachers. However, majority $(80.1 \%)$ perceived that the learning of children with special educational needs can effectively be supported in regular classroom in Ghana with the necessary arrangements.

More than half $(55 \%)$ of the pre-service teachers established disagreement to the statement that it is the right of a child with special education needs to get into special educational classroom in Ghana whiles thirty-one (35.1\%) agreed to the statement. This implies that children with special need education are not restricted to be in special schools. However, the finding indicated that a child with educational need can be moved to special need classroom in order not to violate his/her legal right to education.

From the finding, sixty percent $(60 \%)$ of the pre-service teachers specified that integrating children with special needs education will create extra work for the teachers in the regular classrooms in Ghana and hence majority (74.9\%) were of the view that the education of children with special needs should be arranged as far as possible in the regular classrooms in Ghana. This explains that the implementation of inclusive education requires much more arrangements since there would be additional work on teachers. This finding complements the recommendation suggesting that the Ghana Education Service must provide regular inservice training to teachers for them to be able to address the learning needs of children with special needs education in an inclusive classroom (Ocloo \& Subbey, 2008).

\section{Attitude of Pre-Service Teachers towards Inclusive Education}

A semi-structured interview was conducted to get further explanation to the quantitative data obtained with the questionnaire. The interviews were transcribed for the purpose of the analysis in order not to miss out any important details. In the interview session, respondent got the opportunity to confirm and to express further concerns about inclusive education in Ghana. It was apparent from the interview that pre-service teachers believed that inclusive education is possible in Ghana and when it is fully implemented learners with special education needs will feel much more accepted and hence enhance the quality of education to all persons.

\section{Theme 1 - Positive Attitudes of Preservice Teachers}

The pre-service teachers were of the view that learners with special education needs should be placed in regular classroom together with learners without special education needs and in so doing they would be treated equally. They also stated that the rights of students with special education needs should not be compromised, as mandated by SDG 4, which calls for states to provide inclusive and equitable quality education and encourage lifelong learning 
opportunities for everyone. However, they posited that inclusion should be done after certain measures have been taken into consideration to fully support learners with special needs in the regular classroom. When they were asked about 'How should learners with special education needs be treated'? The following are some of the excerpts from the various interviews:

"They (students with special education needs) should be put in the normal classroom, (have their needs) addressed and be treated equally by involving them in all (school) activities".

"Learners with special education needs should be treated equally as other learners. Their rights should not be violated".

"It should be noted that, the accommodation of students with SEN in the regular or normal classroom highly depends on some key factors. And there is the need for these factors to be considered before any decision is taken".

"Inclusive education is a very good initiative for national development and creating a sense of belonging among people with disability. Student with special education needs need support and so we should help those with special needs."

Theme 2 - Including learners in regular schools is a good idea

If you wish, you may write in the first person singular or plural and use the active voice ("I observed that ..." or "We observed that ..." instead of "It was observed that ..."). Remember to check spelling. If your native language is not English, please get a native English-speaking colleague to proofread your paper.

The finding revealed that the inclusion of learners with special education needs will be an opportunity to improve the holistic development of such learners. They further indicated that inclusive education will make learners with special needs education feel belonging in the society and hence improve their contributions in the society.

"Children with special educational needs in a regular classroom will really enhance their emotional status for them to feel belonging in the society not only that but many to be mentioned, so inclusive education to me is very good if the necessary arrangement is made towards it."

"There should be a gender inclusive at levels to make them feel as they are not rejected, yes, even though it needs extra work in order to achieve this, the class teacher really needs to work hard."

"Children with special needs should be handled with care and much attention should be given to them."

"I strongly agree and believes it would be better if learners with special education needs are placed in a regular classroom."

"Children with special educational needs will learn best in regular classroom when they mixed with the "nondisabilities."

"Inclusive education is a good idea for children to learn side by side."

"Some Special educational need child can even perform better than those without any need."
Relatedly, this finding supports the assertions that the implementation of inclusive education (IE) could increase the number of those with disabilities receiving education and other services in schools and hence help exploit their potentials (Eleweke \& Rodda, 2010).

Theme 3 -Resources for the Implementation of Inclusive Education in Ghana

On a further probe through the interview, the pre-service teachers additionally stated that Ghana at the moment needs to improve upon the current infrastructure in the education sector in order to effectively implement inclusive education. Below are some of the excerpts from the interview, when respondents were asked about whether or not Ghana can implement inclusive education considering the resources required:

"No please, all necessary arrangement should be made before implementing such curriculum, it is good that student with SEN should learn with those without under the same roof, so when they move out they won't be any kind of segregation."

"Inclusive education will only be effective when the infrastructures and educational policies in Ghana provide room for children with special needs but for now there is nothing like that."

"There should be available resources and teaching personnel to teach the subject Inclusive School Based Enquiry and children with special Educational Needs in all regular schools."

"Resources should be provided to support special education needs for Inclusive Education to be possible in Ghana."

These findings back up the conclusions of Kuyini et al. (2016), who highlighted teaching materials, support teachers, and more training as critical support resources that will improve the success of inclusive education. Furthermore, the finding supports the claim that there are insufficient facilities for teachers to implement the inclusion policy, as well as a lack of proper training for instructors to be competent to care for kids with disabilities in their classrooms (Ocloo \& Subbey, 2008).

\section{CONCLUSION}

The findings revealed that all the pre-service teachers have positive attitude towards the implementation of inclusive education. They believed that inclusive education is possible and can be implemented in Ghana. This was attributed to a number of perceived ideas about inclusive education. Among the major ideas were that:

1. children with special education needs are not legally restricted to be in special schools and hence have the legal right to be in regular schools.

2. Inclusive education will bring out the best from learners with special education needs as they will feel belonging in the society.

3. The current educational system in Ghana requires infrastructure advancement to ensure the effective implementation of inclusive education

4. Inclusive Education requires resources provision to be fully and effectively implemented. 


\section{RECOMMENDATIONS}

The government of Ghana and the Ghana Education Service should work together to ensure that there is the availability of adequate facilities for teachers to effectively implement Inclusive Education as enshrined in the new Bachelor of Education Curriculum for Basic Education and Training.

\section{CONFLICT OF INTEREST}

Authors declare that they do not have any conflict of interest.

\section{REFERENCES}

Altintaş, E. \& Şengül, S. (2014). The evaluation of special education courses in terms of educational attainments of pre-service mathematics teachers. Electronic Turkish Studies, 9(2).

Avramidis, E. \& Norwich, B. (2002). Teachers' attitudes towards integration/inclusion: a review of the literature. European journal of special needs education, 17(2), 129-147.

Avramidis, E., Bayliss, P. \& Burden, R. (2000). A survey into mainstream teachers' attitudes towards the inclusion of children with special educational needs in the ordinary school in one local education authority. Educational psychology, 20(2), 191-211.

Costello, S. \& Boyle, C. (2013). Pre-service secondary teachers' attitudes towards inclusive education. Australian Journal of Teacher Education, 38(4), 8.

Costello, S. \& Boyle, C. (2013). Pre-service secondary teachers' attitudes towards inclusive education. Australian Journal of Teacher Education, 38(4), 8.

Creswell, J. W. (2008). Educational research: Planning, conducting, and evaluating quantitative and qualitative research (3rd ed.). Upper Saddle River, NJ: Pearson Education, Inc.

Dias, P. C. \& Cadime, I. (2016). Effects of personal and professional factors on teachers' attitudes towards inclusion in preschool, European Journal of Special Needs Education, 31:1, 111123, DOI: $10.1080 / 08856257.2015 .1108040$

Sharma, U., Loreman, T. \& Forlin, C. (2007). An international comparison of pre-service teacher attitudes towards inclusive education. Disability studies quarterly, 27(4).

Hemmings, B. \& Woodcock, S. (2011). Preservice teachers' views of inclusive education: A content analysis. Australasian Journal of Special Education, 35(2), 103-116

Kim, K. J. \& Taylor, L. K. (2016). Preservice Teachers' Self-Efficacy in Working with Families: Can an Immersive Course Make a Difference?. In Family involvement in early education and child care. Emerald Group Publishing Limited.

Kraska, J. \& Boyle, C. (2014). Attitudes of preschool and primary school pre-service teachers towards inclusive education. Asia-Pacific Journal of Teacher Education, 42(3), 228-246.

Kuyini, A. B., Yeboah, K. A., Das, A. K., Alhassan, A. M., Mangope, B (2016). Ghanaian teachers: Competencies perceived as important for inclusive education. International Journal of Inclusive Education, 20, 1009-1023. doi:10.1080/13603116.2016.1145261

Leatherman, J. M. and Judith, A. N. (2005). Teachers' Attitudes toward Inclusion: Factors Influencing Classroom Practice. Journal of Early Childhood Teacher Education, 26, 23-36.

Markova, M., Pit-Ten, C. I., Krolak-Schwerdt, S. \& Glock, S. (2016). Preservice teachers' attitudes toward inclusion and toward students with special educational needs from different ethnic backgrounds. The Journal of Experimental Education, 84(3), 554-578.

MOE (2018). A New Teacher Education Curriculum to Ensure Quality Teaching And Learning

Nketsia, W. \& Saloviita, T. (2013). Pre-service teachers' views on inclusive education in Ghana. Journal of Education for Teaching. International Research and Pedagogy, 39(4) DOI: 10.1080/02607476.2013.797291

Ocloo, M. A. \& Subbey, M. (2008). Perception of basic education school teachers towards inclusive education in the Hohoe District of Ghana. International Journal of Inclusive Education, 12, 5-6.

Pearman, E. L., Huang, A. M. \& Mellblom, C. I. (1997). The inclusion of all students: Concerns and incentives of educators. Education and Training in Mental Retardation and Developmental Disabilities, $33,11-20$

Saloviita, T. (2015). Measuring pre-service teachers' attitudes towards inclusive education: Psychometric properties of the TAIS scale. Teaching and Teacher Education, 52 (November), 66-72. doi:10.1016/j.tate.2015.09.003

Sharma, U., Forlin, C. \& Loreman, T. (2008). Impact of training on preservice teachers' attitudes and concerns about inclusive education and sentiments about persons with disabilities. Disability \& Society, 23(7), 773-785.

Smith, M. K. \& Smith, K. E. (2000). "I believe in inclusion, but...": Regular education early childhood teachers' perceptions of successful inclusion. Journal of Research in Childhood Education, 14(2), 161-180.

Snyder, R. F. (1999). Inclusion: A qualitative study of in-service general education teachers' attitudes and concerns. Education, 120(1), 173180 .

Sokal, L. \& Sharma, U. (2017). Do I really need a course to learn to teach students with disabilities? I've been doing it for years. Canadian Journal of Education/Revue canadienne de l'éducation, 40(4), 739760.

Subban, P. \& Sharma, U. (2005). Understanding educator attitudes toward the implementation of inclusive education. Disability studies quarterly, 25(2).

Symeonidou, S. \& Phtiaka, H. (2009). Using teachers' prior knowledge, attitudes and beliefs to develop in-service teacher education courses for inclusion. Teaching and Teacher Education, 25(4), 543-550.

Symeonidou, S. \& Phtiaka, H. (2009). Using teachers' prior knowledge, attitudes and beliefs to develop in-service teacher education courses for inclusion. Teaching and Teacher Education, 25(4), 543-550.

Todorovic, J., Stojiljkovic, S., Ristanic, S. \& Djigic, G. (2011). Attitudes towards inclusive education and dimensions of teacher's personality. Procedia-Social and Behavioral Sciences, 29, 426-432.

Treder, D. W., Morse, W. C. \& Ferron, J. M. (2000). The relationship between teacher effectiveness and teacher attitudes toward issues related to inclusion. Teacher Education and Special Education, 23(3), 202-210.

UNESCO (1994). The Salamanca Statement and Framework for Action on Special Needs.

Wiley, K. (1993). Teachers' and students' attitudes to integration. Australian Journal of Early Childhood, 18(2), 39-44. 